\title{
OPTIMASI FORMULA KUAH JAHE DALAM PENGEMBANGAN WEDANG TAHU SEBAGAI PANGAN FUNGSIONAL
}

\author{
[Optimation of Ginger Drink's Formula on Development of Soft Tofu Dessert \\ as a Functional Food]
}

\author{
Nurheni Sri Palupi ${ }^{1,2) \star}$, Larasati Ines Wardiani ${ }^{1}$, dan Budi Nurtama ${ }^{1,2)}$ \\ 1) Departemen Ilmu dan Teknologi Pangan, Fakultas Teknologi Pertanian, Institut Pertanian Bogor, Bogor \\ 2) Southeast Asian Food and Agricultural Science and Technology Center, Institut Pertanian Bogor, Bogor
}

Diterima 11 April 2016 / Disetujui 22 Juni 2016

\begin{abstract}
Soft tofu dessert is a traditional food made from soft tofu and ginger drink. The traditional ginger drink contains antioxidant compounds. There are many varieties of ginger in Indonesia which have different antioxidant activities. Partially subtitution of Zingiber officinale var. Rubrum by Zingiber officinale var. Amarum was expected to improve sensory characteristics and antioxidant activity of traditional ginger drink. The objective of this research was to improve the formula of ginger drink based on sensory characteristics and antioxidant activity in the development of soft tofu dessert as a functional food. Optimization was done by Response Surface Methodology (RSM) based on the value of lightness (L) and 'Hue of ginger drink which measured by Chromameter and antioxidant activity determined by DPPH method. Independent variables using in this optimization were the concentration of ginger and brown sugar. The optimal formula of ginger drink and its application in soft tofu dessert were analyzed by the hedonic rating method. The result of optimal formula consisted of $10.00 \%$ Zingiber officinale var. Rubrum, 9.99\% Zingiber officinale var. Amarum, and $10.00 \%$ brown sugar with a desirability value of 0.822 . The antioxidant activity of the optimal formula of ginger drink was AEAC 553.40 ppm, lightness ( $L$ ) value was 40.03, and ${ }^{\circ}$ Hue was 74.67. The result of sensory test showed that the panelist preference for optimal formula was higher than for the traditional formula of ginger drink, while the acceptance level of the optimal formula was also higher than the tradisional formula of soft tofu dessert.
\end{abstract}

Keywords: antioxidants, DPPH, ginger, response surface method, soft tofu dessert

\begin{abstract}
ABSTRAK
Wedang tahu merupakan pangan tradisional yang berbahan baku tahu lembut dan kuah jahe yang dikenal banyak mengandung senyawa antioksidan. Di Indonesia, terdapat beberapa varietas jahe dengan aktivitas antioksidan yang berbeda-beda. Substitusi sebagian jahe emprit dengan jahe merah diharapkan dapat meningkatkan karakteristik sensori dan aktivitas antioksidan kuah jahe. Penelitian bertujuan memperoleh formula kuah jahe dengan karaktersitik sensori dan aktivitas antioksidan optimal yang akan digunakan dalam pengembangan wedang tahu sebagai pangan fungsional. Optimasi formula kuah jahe dilakukan berdasarkan metode Response Surface Methodology (RSM) dengan variabel bebas berupa konsentrasi jahe merah, jahe emprit dan gula merah. Respon yang digunakan dalam penentuan formula kuah jahe optimal adalah respon kecerahan (nilai L) dan warna (nilai ${ }^{\circ}$ Hue) yang dianalisis dengan Chromameter, serta aktivitas antioksidan dengan metode DPPH. Formula optimal selanjutnya dianalisis kadar air dan analisis aktivitas antioksidan. Tingkat kesukaan panelis terhadap kuah jahe formula optimal dan aplikasinya pada wedang tahu dianalisis dengan metode rating hedonik. Hasil analisis menunjukkan bahwa formula optimal yang diperoleh berdasarkan analisis RSM terdiri dari 10,00\% jahe merah, 9,99\% jahe emprit dan $10 \%$ gula merah dengan nilai desirability 0,822. Aktivitas antioksidan formula tersebut adalah 553,40 ppm AEAC, dengan penampakan cerah (nilai $L=40,03$ dari rentang nilai kecerahan 33,3548,99 ) dan warna kuning kemerahan (nilai ${ }^{\circ} \mathrm{Hue}=74,67$ ). Kuah jahe dan wedang tahu formula optimal lebih disukai panelis dibandingkan dengan kuah jahe dan wedang tahu formula tradisional.
\end{abstract}

Kata kunci: antioksidan, DPPH, jahe, response surface method (RSM), wedang tahu

*Penulis Korespondensi:

E-mail: hnpalupi@yahoo.com 


\section{PENDAHULUAN}

Wedang tahu merupakan salah satu pangan tradisional yang terdiri atas dua komponen, yaitu tahu lembut dan kuah jahe. Umumnya wedang tahu dikonsumsi sebagai makanan selingan diantara dua waktu makan utama atau sebagai pencuci mulut atau dessert. Karakteristik wedang tahu dipengaruhi oleh komposisi dan jenis bahan baku yang digunakan. Tahu lembut (silken tofu) merupakan produk yang dihasilkan dari penggumpalan protein kedelai dan memiliki tekstur yang lunak. Proses pembuatan tahu lembut sama seperti pembuatan tahu pada umumnya, namun tidak dilakukan pengepresan. Kuah jahe berupa minuman yang berbahan baku jahe dengan ditambahkan gula merah, gula pasir, air, dan garam. Kuah jahe memiliki karakteristik yang serupa dengan wedang jahe, namun berbeda dari sisi warna dan komposisi gula yang digunakan. Pada pembuatan kuah jahe ditambahkan gula merah sehingga berwarna coklat, sedangkan wedang jahe umumnya dibuat tanpa penambahan gula merah dan berwarna putihkekuningan, meskipun terdapat beberapa wedang jahe yang menggunakan gula merah. Selain mempengaruhi warna kuah jahe, gula merah juga berkontribusi dalam menghasilkan rasa manis pada kuah jahe. Selama ini pembuatan wedang tahu masih dilakukan secara tradisional menggunakan cara pengolahan sederhana berdasarkan kebiasaan secara turun-temurun, sehingga belum tersedia formula standar untuk menghasilkan wedang tahu dengan kualitas yang konstan dan disukai oleh konsumen.

Jahe merupakan bahan baku utama pada pembuatan kuah jahe. Di Indonesia terdapat beberapa varietas jahe diantaranya jahe gajah, jahe emprit, dan jahe merah. Masing-masing varietas tersebut memiliki karakteristik kimia yang berbeda. Menurut Ali et al. (2008), jahe mengandung senyawa antioksidan yang dapat menghambat penyakit degeneratif. Menurut Mayani et al. (2014), aktivitas antioksidan sari jahe berkisar antara 44,91-66,23\%. Terdapat beberapa faktor yang mempengaruhi aktivitas antioksidan sari jahe, seperti suhu dan waktu ekstraksi. Menurut Ibrahim et al. (2015), suhu $95^{\circ} \mathrm{C}$ merupakan suhu optimal untuk menghasilkan aktivitas antioksidan pada sari jahe, dengan waktu ekstraksi 25 menit. Selain itu, varietas jahe dan konsentrasi jahe yang digunakan diduga dapat mempengaruhi aktivitas antioksidan kuah jahe yang dihasilkan. Substitusi jahe merah (Zingiber officinale var. Rubrum) dan jahe emprit (Zingiber officinale var. Amarum) diharapkan dapat meningkatkan karakteristik sensori dan aktivitas antioksidan dalam kuah jahe.

Penerimaan konsumen terhadap suatu produk pangan ditentukan oleh beberapa parameter, di- antaranya warna. Warna suatu produk dapat dianalisis secara objektif menggunakan instrumen kromameter. Parameter warna yang dapat dianalisis menggunakan kromameter antara lain tingkat kecerahan (nilai L) dan warna (nilai ${ }^{\circ} \mathrm{Hue}$ ). Semakin gelap warna suatu produk ditunjukkan dengan nilai L yang mendekati nol, sedangkan nilai ${ }^{\circ} \mathrm{Hue}$ mendeskripsikan warna produk sebenarnya. Berdasarkan hal tersebut, nilai $L$ dan nilai ${ }^{\circ}$ Hue digunakan sebagai respon penentu dalam pemilihan formula kuah jahe optimal.

Dewasa ini kebutuhan pangan fungsional semakin meningkat sejalan dengan meningkatnya kesadaran masyarakat akan kesehatan. Namun demikian produsen pengembang pangan fungsional sering terkendala dengan ketersediaan bukti ilmiah dalam pengajuan klaim pangan fungsional sebagimana tertuang dalam Perka BPOM RI tahun 2011. Untuk itu penelitian-penelitian tentang produk pangan fungsional perlu didorong untuk memberikan landasan ilmiah sehingga dapat memenuhi ketentuan yang berlaku. Salah satu pangan yang dapat dikembangkan sebagai pangan fungsional adalah pangan dengan kandungan antioksidan tinggi. Menurut IFT (2011), tidak ada kecukupan diet yang direkomendasikan (Recommeded Dietary Allowance (RDA) untuk pemenuhan antioksidan, namun untuk mencukupi kebutuhan antioksidan tubuh dianjurkan mengonsumsi setengah porsi buah dan sayuran dalam hidangan makan utama. Namun demikian berdasarkan LPI (2016), recommended dietary allowance (RDA) antioksidan pangan ditetapkan sebesar $120 \mathrm{mg} /$ hari vitamin $\mathrm{C}$ untuk mengurangi risiko penyakit jantung, stroke, dan kanker pada individu yang sehat. RDA tersebut menunjukkan tingkat asupan diet harian yang cukup untuk memenuhi kebutuhan zat gizi (vitamin C) bagi $97-98 \%$ individu dalam kelompok tertentu. Sebagai ilustrasi kandungan vitamin C (salah satu standar dalam pengukuran kapasitas antioksidan) dalam buah jeruk adalah sebesar 583 ppm, sedangkan dalam jahe 553 ppm. Dengan demikian kuah jahe yang digunakan dalam pembuatan wedang tahu mengandung antioksidan yang relatif tinggi dan oleh karenanya wedang tahu berpotensi dikembangkan sebagai pangan fungsional.

Oleh karena wedang tahu terdiri dari dua komponen utama yaitu tahu lembut dan kuah jahe, maka diperlukan optimasi formula dari keduanya. Penelitian ini difokuskan untuk memperoleh formula kuah jahe dengan karaktersitik sensori dan aktivitas antioksidan optimal berdasarkan jenis dan konsentrasi jahe serta konsentrasi gula merah. Penentuan formula tahu lembut dilaksanakan dalam penelitian secara terpisah. Selain itu juga akan dan aplikasinya pada wedang tahu dengan menggunakan formula tahu lembut komersial. Penelitian bertujuan (1) memperoleh formula kuah jahe optimal berdasarkan 
respon kecerahan dan warna serta aktivitas antioksidannya; (2) menguji karakteristik fisik, kimia, dan sensori kuah jahe formula optimal; serta (3) menguji tingkat kesukaan wedang tahu formula optimal dibandingkan dengan wedang tahu formula tradisonal.

\section{BAHAN DAN METODE}

\section{Bahan}

Bahan-bahan yang digunakan dalam penelitian ini berupa dua varietas jahe segar, yaitu jahe merah (jahe sunti) dan jahe emprit (jahe kuning); gula pasir (merk "Gulaku"); dan gula merah (merk "Cap Semut"). Jahe segar diperoleh dari sebuah perkebunan di daerah Klaten dengan usia tanam 10-12 bulan. Rimpang jahe tidak bertunas, tidak terkelupas kulitnya, tidak berkapang dan tidak busuk sehingga memenuhi kriteria mutu jahe segar (BSN, 1992).

Digolongkan menjadi tiga jenis mutu. Spesifikasi persyaratan mutu mencakup kesegaran jahe, rimpang bertunas, bentuk rimpang, kenampakan irisan melintang. Persyaratan umum mencakup ukuran berat, rimpang yang terkelupas kulitnya, benda asing dan rimpang berkapang.

\section{Karakterisasi kimia jahe}

Karakterisasi kimia yang dilakukan terdiri dari analisis kadar air metode oven (SNI 01-2891-1992) dan analisis aktivitas antioksidan metode DPPH (Fayed, 2009). Analisis kadar air dilakukan terhadap rimpang jahe merah dan jahe emprit yang diiris sehingga mencapai berat 1-2 gram. Kemudian dikeringkan dalam oven pengering (WTC Binder seri 7200). Analisis antioksidan dilakukan terhadap ekstrak jahe merah dan jahe emprit. Proses ekstraksi diawali dengan pencucian dan pemarutan jahe (Mayani et al., 2014). Selanjutnya 5 gram parutan jahe dimasukkan ke dalam $50 \mathrm{~mL}$ air yang telah mendidih selama 25 menit (Ibrahim et al., 2015), ekstrak jahe tersebut didinginkan dan disaring. Selanjutnya, ekstrak disentrifugasi pada kecepatan 3000 rpm selama 10 menit menggunakan sentrifuge Biosan seri LMC-4200R (Sovia et al., 2011). Filtrat pada bagian atas digunakan untuk analisis antioksidan. Pembacaan absorbansi dilakukan menggunakan spektrofotometer (Thermo Scientific, Genesys 20) pada panjang gelombang $(\lambda)$ $517 \mathrm{~nm}$ dan hasilnya ditetapkan sebagai ascorbic acid equivalent antioxidant capacity (AEAC) menggunakan kurva standar asam askorbat dengan konsentrasi 0, 100, 200, 300, 400, dan 500 ppm.

\section{Rancangan dan optimasi formula kuah jahe}

Rancangan, analisis dan optimasi formula kuah jahe dilakukan menggunakan response surface me- thodology (RSM) pada aplikasi DX7 dengan desain percobaan Mixture Experiment. Desain percobaan ini melibatkan dua atau lebih komponen dengan komposisi tertentu untuk menghasilkan produk akhir dengan karakteristik tertentu. Rancangan optimasi formula terdiri dari 3 komponen, yaitu jahe merah (0$17,5 \%)$, jahe emprit $(0-12,5 \%)$ dan gula merah $(15 \%)$, yang ditetapkan melaui trial eror pada penelitian pendahuluan sebelumnya. Sedangkan responnya adalah warna (nilai $L$ dan Hue) dan aktivitas antioksidan. Pada umumnya warna merupakan aspek yang penting untuk penerimaan suatu produk sehingga respon warna kuah jahe digunakan sebagai salah satu faktor penentu formula kuah jahe optimal. Nilai L berkisar antara 0 sampai 100. Nilai L sebesar 0 menunjukkan warna hitam, sedangkan nilai L sebesar 100 menunjukkan warna putih (Leon et al., 2006). Parameter warna lainnya yang dapat dianalisis secara objektif adalah ${ }^{\circ}$ Hue. Hue merupakan representasi dari warna sebenarnya (Haryanto, 2009). Nilai 'Hue dapat diperoleh dari hasil perhitungan antara nilai a dan nilai b, yaitu arctan a/b (Huncthing, 1999 dalam Hidayati, 2007). Antioksidan adalah suatu senyawa yang bermanfaat melindungi sel tubuh dari kerusakan akibat radikal bebas.

Kisaran minimum dan maksimum ditentukan berdasarkan hasil trial and error dan hasil analisis rating intensitas rasa pedas dan aroma yang dilakukan oleh 10 orang panelis ahli (expert panel) terhadap 7 kombinasi formula, yaitu jahe merah (0$17,5 \%)$, jahe emprit $(0-12,5 \%)$. Batas konsentrasi jahe ditentukan berdasarkan konsentrasi jahe yang dinilai panelis memiliki intensitas aroma dan rasa tertinggi, namun belum menghasilkan rasa pahit. Penilaian menggunakan skala intensitas dengan rentang 1-7, semakin besar skor intensitas menunjukkan bahwa sampel memiliki intensitas atribut yang semakin kuat. Sedangkan batas konsentrasi gula merah ditentukan berdasarkan penilaian oleh panelis terhadap atribut warna dan rasa manis kuah jahe yang dibuat dengan tiga konsentrasi gula merah $(15,20$, dan $25 \%$ ) dan jahe emprit dengan konsentrasi $10 \%$ (g/100 mL air).

Formula optimal ditentukan berdasarkan hasil analisis respon kecerahan warna kuah jahe (nilai L) dan nilai ${ }^{\circ}$ Hue dan aktivitas antioksidan dari formula hasil analisis RSM. Analisis kecerahan warna kuah jahe (nilai $L$ ) dan nilai ${ }^{\circ}$ Hue dilakukan dengan menggunakan Chromameter (Konica Minolta Seri CR-310). Optimasi dilakukan untuk memperoleh kuah jahe dengan warna coklat cerah dan memiliki aktivitas antioksidan yang paling tinggi. Pengujian aktivitas antioksidan menggunakan metode DPPH dengan (1,1-diphenyl-2-picrylhydrazyl) (Sigma, Germany) (Fayed, 2009). 


\section{Karakterisasi kimia kuah jahe formula optimal}

Sebelum dianalisis, jahe dicuci tanpa dikupas untuk meminimalkan hilangnya senyawa oleoresin pada lapisan epidermis jahe. Sebelum dilakukan perebusan atau ekstraksi, jahe digeprek terlebih dahulu. Karakteristik sensori sari jahe yang dibuat dengan cara digeprek lebih disukai panelis dibandingkan dengan cara pengecilan ukuran jahe, seperti diparut dan diris (Mayani et al., 2014). Jahe kemudian direbus pada suhu $90-95^{\circ} \mathrm{C}$ (Ibrahim et al., 2015). Setelah 20 menit perebusan, dilakukan penambahan gula dan dilanjutkan perebusan selama 5 menit. Hasil rebusan diendapkan, kemudian disaring untuk memisahkan antara sari jahe dengan ampas atau kotoran lain.

Karakterisasi kimia kuah jahe formula terpilih dilakukan dengan analisis kadar air metode oven (AOAC, 2012); analisis kadar abu dengan metode pengabuan kering (AOAC, 2012); analisis kadar lemak metode soxhlet (AOAC, 2012); analisis kadar protein metode kjeldahl (AOAC, 2012); dan penentuan kadar karbohidrat dilakukan secara berdasarkan perhitungan by different.

\section{Karakterisasi sensori kuah jahe dan wedang tahu formula optimal}

Kuah jahe formula optimal dan wedang tahu optimal, yang dibuat menggunakan kuah jahe formula optimal dan tahu lembut formula optimal (Indrastuti, 2015), selanjutnya dianalisis sensori (BSN, 2006). Sebagai pembanding digunakan wedang tahu yang dibuat dengan formula tradisional dari pedagang wedang tahu. Tingkat kesukaan terhadap kuah jahe dan wedang tahu formula optimal dianalisis dengan metode rating hedonik (Meilgaard et al., 2006) menggunakan 70 orang panelis tidak terlatih yang menyukai wedang jahe maupun produk jahe lainnya. Sampel disajikan dalam kondisi hangat secara satu per satu untuk menghidari panelis membandingkan kedua sampel tersebut. Suhu kedua sampel dijaga agar tetap sama untuk menghindari bias (Meilgaard et al., 2006). Penilaian panelis terhadap produk kuah jahe meliputi aroma, warna, rasa, serta secara keseluruhan (overall), sedangkan penilaian terhadap wedang tahu ditambahkan aspek tekstur. Penilaian menggunakan skala hedonik dengan rentang 1 (sangat tidak suka) sampai 7 (sangat suka). Hasil analisis dua produk (kuah jahe dan wedang tahu) formula optimal selanjutnya dibandingkan dengan formula tradisional dan diolah dengan uji inde-pendent $T$-test menggunakan program SPSS 20.0.

\section{HASIL DAN PEMBAHASAN}

\section{Karakteristik kimia jahe}

Jahe merah memiliki kadar air $(84,57 \pm 0,25 \%$ bb), lebih tinggi dibandingkan jahe emprit $(80,55 \pm$ $0,41 \% \mathrm{bb}$ ) (Tabel 2). Data tersebut sesuai dengan hasil penelitian Julianti et al. (2010) yang menunjukkan bahwa jahe merah memiliki kadar air tertinggi, kemudian jahe gajah, dan jahe emprit. Menurut Depkes RI (2010), kadar air jahe segar adalah $86,2 \%$, sedangkan menurut Puengphian dan Sirichote (2008) kadar air jahe gajah segar adalah $94,17 \%$. Perbedaan kadar air jahe tersebut dapat disebabkan oleh perbedaan lingkungan tumbuh antara jahe yang digunakan (Ali et al., 2008). Selain itu, perbedaan umur panen juga dapat mempengaruhi kadar air jahe, semakin lama umur panen, maka kadar air jahe semakin rendah (Julianti et al., 2010). Meskipun demikian, pada penelitian ini faktor-faktor tersebut telah diminimalkan dengan menggunakan jahe segar yang diperoleh dari sebuah perkebunan di daerah Klaten dengan usia tanam 10-12 bulan dan memenuhi standar mutu jahe segar (BSN, 1992). Dengan demikian perbedaan kadar air yang terjadi disebabkan oleh adanya perbedaan varietas jahe.

Aktivitas antioksidan jahe merah lebih tinggi $(80,25 \pm 0,04 \%$ atau setara dengan $849,19 \pm 0,44$ ppm AEAC) dibandingkan jahe emprit (79,64 \pm $0,03 \%$ atau $844,50 \pm 0,88 \mathrm{ppm}$ AEAC). Hal ini sejalan dengan hasil penelitian Herold (2007) yang menunjukkan bahwa aktivitas antioksidan jahe merah lebih besar dibandingkan jahe emprit. Oleoresin merupakan komponen penting pada jahe yang mengandung senyawa fenol sehingga dapat berperan sebagai antioksidan. Senyawa fenolik yang terkandung pada jahe adalah gingerol dan shogaol (Battarai et al., 2001). Senyawa fenolik merupakan senyawa yang bersifat polar dan dapat menangkap radikal bebas, serta dapat meredam terbentuknya singlet oksigen (Marliyana et al., 2006).

\section{Rancangan dan respon optimasi formula kuah jahe}

Berdasarkan rekomendasi analisis data variabel (konsentrasi jahe merah, jahe emprit dan gula merah) dan respon (nilai L, 'Hue dan aktivitas antioksidan) menggunakan metode respone surface methodology (RSM) dengan rancangan D-optimal, terdapat 16 rancangan optimasi formula yang harus diujikan (Tabel 1) sesuai dengan batas bawah dan batas atas untuk setiap komponen (Tabel 3 ). 
Tabel 1. Rancangan dan respon optimasi formula kuah jahe

\begin{tabular}{ccccccc}
\hline \multirow{2}{*}{ Formula } & \multicolumn{3}{c}{ Komponen $(\mathrm{g} / 100 \mathrm{~mL}$ Air) } & Respon \\
\cline { 2 - 7 } & Jahe Merah & Jahe Emprit & Gula Merah & Aktivitas Antioksidan & Kecerahan $(\mathrm{L})$ & Warna ${ }^{\circ} \mathrm{Hue}$ \\
\hline 1 & 5 & 10 & 15 & $383,27 \pm 0,07$ & $33,35 \pm 0,05$ & $56,30 \pm 0,08$ \\
2 & 8,42 & 10 & 11,58 & $525,45 \pm 0,06$ & $37,13 \pm 0,04$ & $64,21 \pm 0,07$ \\
3 & 5 & 10 & 15 & $384,18 \pm 0,08$ & $36,80 \pm 0,01$ & $58,48 \pm 0,08$ \\
4 & 15 & 10 & 5 & $554,08 \pm 0,04$ & $40,28 \pm 0,00$ & $73,73 \pm 0,00$ \\
5 & 15 & 5,25 & 9,75 & $542,91 \pm 0,08$ & $38,47 \pm 0,04$ & $64,29 \pm 0,06$ \\
6 & 14,32 & 0,68 & 15 & $312,68 \pm 0,02$ & $36,70 \pm 0,01$ & $55,83 \pm 0,02$ \\
7 & 15 & 10 & 5 & $553,16 \pm 0,08$ & $43,60 \pm 0,00$ & $75,47 \pm 0,00$ \\
8 & 15 & 2,61 & 12,39 & $464,30 \pm 0,08$ & $38,63 \pm 0,03$ & $63,02 \pm 0,02$ \\
9 & 10,92 & 7,16 & 11,92 & $490,04 \pm 0,09$ & $35,87 \pm 0,02$ & $58,82 \pm 0,07$ \\
10 & 11,38 & 3,62 & 15 & $333,23 \pm 0,03$ & $38,61 \pm 0,07$ & $56,62 \pm 0,03$ \\
11 & 8,42 & 10 & 11,58 & $515,05 \pm 0,04$ & $36,80 \pm 0,01$ & $68,37 \pm 0,05$ \\
12 & 15 & 5,25 & 9,75 & $522,32 \pm 0,07$ & $48,99 \pm 0,01$ & $71,91 \pm 0,02$ \\
13 & 12,78 & 4,09 & 13,13 & $440,05 \pm 0,06$ & $41,81 \pm 0,01$ & $66,66 \pm 0,02$ \\
14 & 14,32 & 0,68 & 15 & $303,00 \pm 0,19$ & $40,67 \pm 0,01$ & $66,89 \pm 0,04$ \\
15 & 9,35 & 5,65 & 15 & $373,68 \pm 0,01$ & $37,74 \pm 0,01$ & $57,54 \pm 0,05$ \\
16 & 12,2 & 9,01 & 8,79 & $546,09 \pm 0,11$ & $41,48 \pm 0,03$ & $67,95 \pm 0,03$ \\
\hline
\end{tabular}

Tabel 2. Respon kecerahan, warna dan aktivitas antioksidan kuah jahe

\begin{tabular}{|c|c|c|c|c|c|c|}
\hline Parameter & Persamaan & $\begin{array}{c}\text { Tingkat } \\
\text { Signifikansi }(p) \\
\end{array}$ & $\begin{array}{c}\text { Lack of } \\
\text { Fit }\end{array}$ & $\begin{array}{c}\text { Adj } R- \\
\text { squared }\end{array}$ & $\begin{array}{l}\text { Pred } R- \\
\text { squared }\end{array}$ & $\begin{array}{c}\text { Adeq } \\
\text { Precision }\end{array}$ \\
\hline Kecerahan & $\begin{array}{l}\text { Kecerahan }(\mathrm{L})= \\
1,74 \mathrm{~A}+1,21 \mathrm{~B}+0,93 \mathrm{C}\end{array}$ & $\begin{array}{l}\text { Signifikan } \\
(p=0,0195)\end{array}$ & TS & 0,3703 & 0,2178 & 6,3814 \\
\hline $\begin{array}{l}\text { Warna } \\
\text { ('Hue) }\end{array}$ & $\begin{array}{l}\text { Warna (Hue) }= \\
2,87 \mathrm{~A}+2,60 \mathrm{~B}+1,16 \mathrm{C}\end{array}$ & $\begin{array}{l}\text { Signifikan } \\
(p=0,0003)\end{array}$ & TS & 0,6764 & 0,5851 & 10,8204 \\
\hline $\begin{array}{l}\text { Aktivitas } \\
\text { antioksidan }\end{array}$ & $\begin{array}{l}\text { Aktivitas antioksidan }= \\
13,39 \mathrm{~A}+3,66 \mathrm{~B}-40,33 \mathrm{C}+ \\
0,46 \mathrm{AB}+3,14 \mathrm{AC}+4,19 \mathrm{BC}\end{array}$ & $\begin{array}{l}\text { Signifikan } \\
(p<0,0001)\end{array}$ & TS & 0,983816 & 0,974203 & 35,20383 \\
\hline
\end{tabular}

Keterangan: $\mathrm{A}=$ konsentrasi jahe merah; $\mathrm{B}=$ konsentrasi jahe emprit; $\mathrm{C}=$ konsentrasi gula merah; $\mathrm{TS}=$ tidak signifikan; Adj = adjusted; Pred $=$ predicted; Adeq $=$ Adequate

Respon kecerahan (nilai L) kuah jahe dari 16 formula yang diperoleh berkisar 33,35-48,99 (Gambar 1), warna (nilai ${ }^{\circ} \mathrm{Hue}$ ) 55,83-75,47 (Gambar 2), dan aktivitas antioksidan 303-554,08 ppm AEAC (Gambar 3). Sedangkan persamaan matematika respon kecerahan, warna dan aktivitas antioksidan dapat dilihat pada Tabel 2, yang dilengkapi dengan dengan nilai-nilai yang menunjukkan kualitas data dari setiap persamaan matematika yang tersebut (Lack of Fit, Adj R-squared, Pred R-squared dan Adeq Precision).

Tabel 3. Kriteria pemilihan formula kuah jahe optimal

\begin{tabular}{lcccc}
\hline Variabel & Goal & $\begin{array}{c}\text { Batas } \\
\text { Bawah }\end{array}$ & $\begin{array}{c}\text { Batas } \\
\text { Atas }\end{array}$ & $\begin{array}{c}\text { Skala } \\
\text { Kepen- } \\
\text { tingan }\end{array}$ \\
\hline Jahe merah & dalam rentang & 5,00 & 15,00 & +++ \\
Jahe emprit & dalam rentang & 0,68 & 10,00 & +++ \\
$\begin{array}{l}\text { Gula merah } \\
\text { Aktivitas }\end{array}$ & dalam rentang & 5,00 & 15,00 & +++ \\
$\begin{array}{l}\text { antioksidan } \\
\text { Kecerahan }\end{array}$ & dimaksimalkan & 303,00 & 554,08 & ++++ \\
$\begin{array}{l}\text { dimaksimalkan }(\text { L) } \\
\text { Nilai Hue }\end{array}$ & dimaksimalkan & 53,35 & 48,93 & +++++ \\
\hline
\end{tabular}

Semakin tinggi nilai $\mathrm{L}$ menunjukkan semakin cerah warna kuah jahe yang dihasilkan. Berdasarkan persamaan nilai $L$ diketahui bahwa kecerahan warna pada kuah jahe dipengaruhi oleh komposisi jahe merah, jahe emprit, serta gula merah. Peningkatan konsentrasi dari masing-masing bahan tersebut dapat meningkatkan kecerahan warna kuah jahe yang dihasilkan. Nilai koefisien pada masing-masing variabel (bahan) menunjukkan bahwa komposisi jahe merah dan jahe emprit memberikan pengaruh lebih besar terhadap kecerahan warna kuah jahe dibandingkan dengan komposisi gula merah. Hal ini sesuai dengan hasil penelitian Ibrahim et al. (2015) yang menyatakan bahwa dengan adanya penambahan konsentrasi jahe, dapat meningkatkan kecerahan produk.

Rentang nilai ${ }^{\circ} \mathrm{Hue}$ menunjukkan bahwa warna sampel kuah jahe merupakan kombinasi warna kuning dan merah. Berdasarkan persamaan respon warna (nilai ${ }^{\circ} \mathrm{Hue}$ ), diketahui bahwa ketiga komponen mempengaruhi respon warna pada kuah jahe. Peningkatan konsentrasi masing-masing bahan tersebut dapat meningkatkan intensitas warna coklat kekuningan kuah jahe yang dihasilkan. 


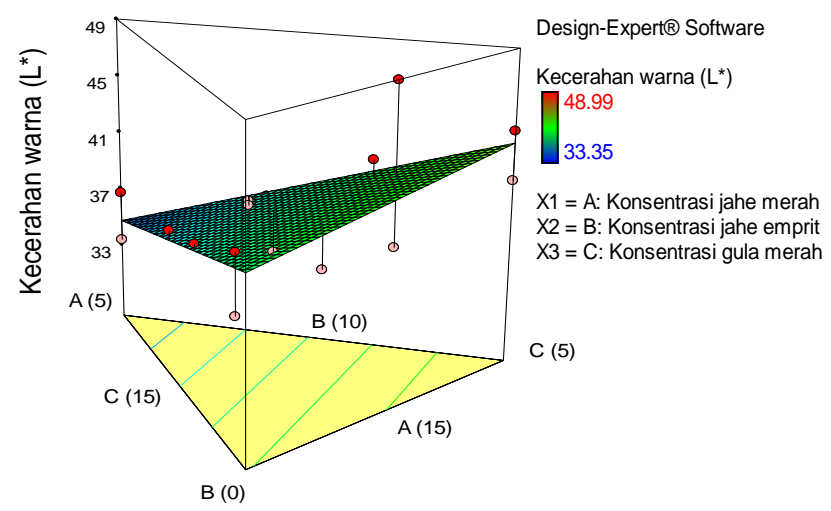

Gambar 1. Respon kecerahan warna (L) kuah jahe berdasarkan komposisi jahe merah, jahe emprit, dan gula merah

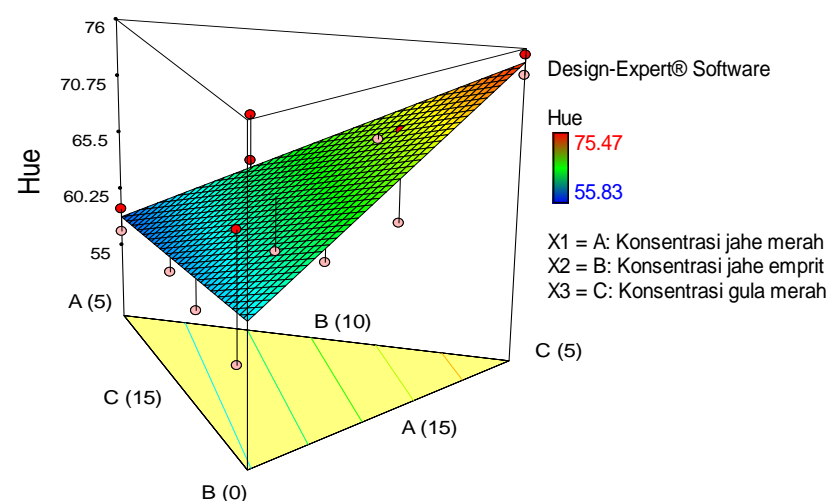

Gambar 2. Respon warna ( $\left.{ }^{\circ} \mathrm{Hue}\right)$ kuah jahe berdasarkan komposisi jahe merah, jahe emprit, dan gula merah

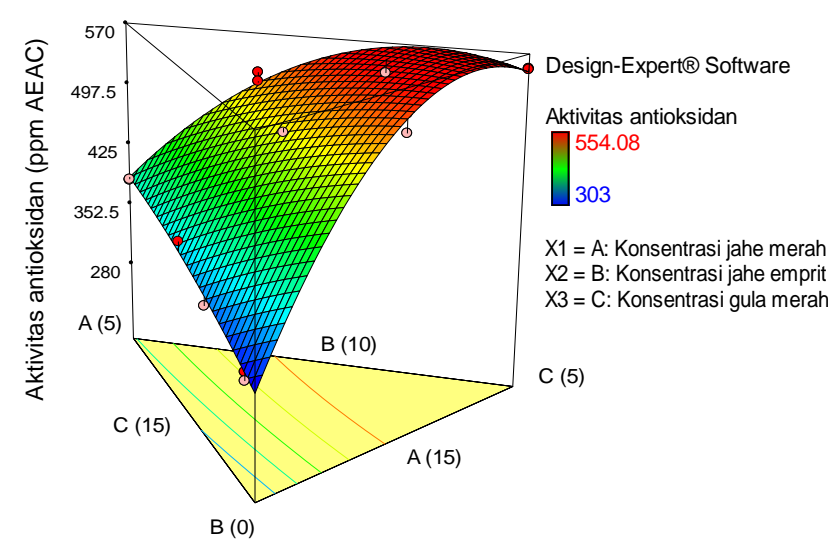

Gambar 3. Respon aktivitas antioksidan kuah jahe berdasarkan komposisi jahe merah, jahe emprit, dan gula merah

Nilai koefisien menunjukkan bahwa respon warna ( $\left.{ }^{\circ} \mathrm{Hue}\right)$ pada kuah jahe lebih dipengaruhi oleh konsentrasi jahe (merah dan emprit) dibandingkan dengan konsentrasi gula merah. Senyawa oleoresin yang berwarna kuning atau kuning kecoklatan
(Oktora et al., 2007) pada jahe diduga menyebabkan nilai ${ }^{\circ}$ Hue pada kuah jahe meningkat.

Berdasarkan persamaan respon aktivitas antioksidan, diketahui bahwa penggunaan kombinasi jahe merah dan jahe emprit dapat meningkatkan aktivitas antioksidan. Nilai koefisien pada variabel jahe merah $(13,39)$ lebih besar dibandingkan koefisien jahe emprit $(3,66)$. Nilai koefisien jahe merah yang tinggi menunjukkan bahwa aktivitas antioksidan kuah jahe lebih dipengaruhi oleh jahe merah dibandingkan jahe emprit. Hal ini didukung dengan kadar antioksidan jahe merah yang lebih tinggi dibandingkan jahe emprit. Koefisien persamaan untuk konsentrasi gula merah bernilai negatif $(-40,33)$, hal ini bermakna bahwa penambahan konsentrasi gula merah dapat menurunkan aktivitas antioksidan kuah jahe. Hasil ini kurang sesuai dengan literatur yang menyatakan bahwa gula merah sendiri mengandung senyawa fenolik yang dapat menghasilkan aktivitas antioksidan (Septiana dan Dwiyanti, 2009). Namun, persamaan two factor interaction tersebut menunjukkan bahwa dengan adanya interaksi gula merah dengan jahe merah maupun interaksi gula merah dengan jahe emprit dapat meningkatkan antioksidan pada kuah jahe.

\section{Formula kuah jahe optimal berdasarkan respon warna dan aktivitas antioksidan}

Pada umumnya secara tradisional pembuatan kuah jahe yang digunakan pada wedang tahu menggunakan jahe emprit. Pada penelitian ini, digunakan kombinasi jahe emprit dengan jahe merah untuk meningkatkan karakterisitik sensori dan aktivitas antioksidan kuah jahe yang dihasilkan. Adapun kriteria yang digunakan dalam penentuan formula kuah jahe optimal dapat dilihat pada Tabel 3. Skala kepentingan respon aktivitas antioksidan ditentukan $4(++++)$ yang nilainya lebih kecil dibandingkan skala kepentingan dari respon kecerahan (L) dan nilai ${ }^{\circ}$ Hue. Respon kecerahan ( $L$ ) dan nilai ${ }^{\circ}$ Hue dianggap paling penting karena pada umumnya konsumen cenderung lebih memperhatikan karakteristik sensori suatu produk dibandingkan senyawa yang terkandung di dalamnya.

Berdasarkan kriteria yang telah ditentukan, diperoleh formula optimal kuah jahe seperti disajikan pada Tabel 4. Adapun kuah jahe formula optimal diperoleh dengan komposisi jahe merah: jahe emprit:gula merah sebesar 10,00:9,99:10,00 dengan nilai desirability $0,822(82,2 \%)$ yang menunjukkan seberapa besar tercapainya seluruh kriteria (memaksimalkan nilai aktivitas antioksidan, kecerahan warna dan nilai ${ }^{\circ} \mathrm{Hue}$ ) yang diinginkan pada tahapan optimasi menggunakan program DX7. Nilai desirability sangat dipengaruhi oleh kompleksitas komponen, rentang komponen, jumlah komponen yang menjadi variabel bebas, jumlah respon yang dianalisis, serta target atau kriteria yang ingin 
dicapai dalam memperoleh formula optimal. Semakin banyak komponen yang menjadi variabel dan semakin lebar rentang dari masing-masing komponen tersebut akan semakin sulit untuk memperoleh formula optimal. Dengan demikian nilai desirability yang kecil mencerminkan semakin sulit untuk memperoleh formula optimal. Verifikasi formula kuah jahe optimal sebagai model yang disarankan oleh program DX 7 dalam memprediksi nilai respon dapat dilihat pada Tabel 5.

Tabel 4. Formula kuah jahe optimal berdasarkan warna ( $\mathrm{L}$ dan ${ }^{\circ} \mathrm{Hue}$ ) dan aktivitas antioksidan

\begin{tabular}{lcc}
\hline Komponen $(\mathrm{g} / 100 \mathrm{~mL})$ & Konsentrasi & Desirability \\
\hline Jahe merah & 10,00 & \\
Jahe emprit & 9,99 & 0,822 \\
Gula merah & 10,00 & \\
\hline
\end{tabular}

Tabel 5. Hasil pengukuran aktual dan nilai prediksi respon kuah jahe optimal

\begin{tabular}{|c|c|c|c|c|}
\hline Respon & Aktual & Prediksi & $\begin{array}{c}95 \% \\
\text { CI Low }\end{array}$ & $\begin{array}{c}95 \% \\
\text { Cl High }\end{array}$ \\
\hline $\begin{array}{l}\text { Aktivitas } \\
\text { antioksidan }\end{array}$ & 553,40 & 554,08 & 537,21 & 570,95 \\
\hline Kecerahan $(\mathrm{L})$ & 40,03 & 42,74 & 39,32 & 46,25 \\
\hline Warna ('Hue) & 74,67 & 74,53 & 70,12 & 78,94 \\
\hline
\end{tabular}

Data aktual respon warna, kecerahan dan aktivitas antioksidan berada pada kisaran confident interval (Cl). Confident Interval (Cl) merupakan rentang yang menunjukkan ekspektasi rata-rata hasil pengukuran pada taraf signifikan tertentu. Nilai Cl 95\% menunjukkan bahwa sebanyak 95\% faktor internal (yang diujikan) dapat mempengaruhi nilai suatu respon, sedangkan 5\% lainnya berasal dari faktor di luar model. Dengan demikian model yang digunakan dalam optimasi formula dapat memprediksi respon dengan baik.

\section{Karakteristik kimia kuah jahe formula optimal dan formula tradisional}

Berdasarkan uji T, komposisi kimia dan aktivitas antioksidan kuah jahe formula optimal berbeda signifikan dengan kuah jahe tradisional. Karakteristik kimia kuah jahe selengkapnya dapat dilihat pada Tabel 6 . Kadar air kuah jahe tradisional $(82,98 \%)$ lebih rendah dibandingkan kuah jahe optimal $(83,77 \%)$ diduga disebabkan karena perbedaan kadar air bahan baku yang digunakan. Kuah jahe formula optimal menggunakan bahan baku kombinasi jahe merah dan jahe emprit, sedangkan kuah jahe tradisional hanya menggunakan jahe emprit. Kadar air jahe merah $(82,52 \%)$ lebih tinggi dibandingkan kadar air jahe emprit $(79,33 \%)$. Kadar abu kuah jahe tradisional dan kuah jahe formula optimal adalah $0,21 \%$ dan $0,24 \%$ (b/b). Kadar protein kuah jahe tradisional adalah $0,30 \%$ dan kadar protein kuah jahe optimal adalah 0,33\%. Kadar lemak kuah jahe formula optimal (1,59\%) lebih rendah dibandingkan kuah jahe tradisional $(0,96 \%)$, diduga karena kuah jahe tradisional tidak menggunakan jahe merah yang mengandung minyak lebih tinggi dibandingkan jahe emprit. Kadar karbohidrat kuah jahe tradisional adalah 15,55\% dan kadar karbohidrat kuah jahe formula optimal adalah $14,07 \%$, diduga dipengaruhi oleh konsentrasi gula merah yang ditambahkan, $12 \mathrm{~g} / 100 \mathrm{~mL}$ pada kuah jahe tradisional dan $9,59 \mathrm{~g} / 100 \mathrm{~mL}$ pada kuah jahe formula optimal.

Tabel 6. Karakteristik kimia kuah jahe optimal dan kuah jahe tradisional

\begin{tabular}{lcc}
\hline \multicolumn{1}{c}{ Parameter } & $\begin{array}{c}\text { Kuah Jahe } \\
\text { Formula } \\
\text { Optimal }\end{array}$ & $\begin{array}{c}\text { Kuah Jahe } \\
\text { Formula } \\
\text { Tradisional }\end{array}$ \\
\hline Kadar air (\%) & $83,77 \pm 0,06^{\mathrm{b}}$ & $82,98 \pm 0,47^{\mathrm{a}}$ \\
Kadar abu (\%) & $0,24 \pm 6,7 \times 10^{-3 \mathrm{~b}}$ & $0,21 \pm 0,04^{\mathrm{a}}$ \\
Kadar lemak (\%) & $1,59 \pm 0,12^{\mathrm{b}}$ & $0,96 \pm 0,01^{\mathrm{a}}$ \\
$\begin{array}{l}\text { Kadar protein } \\
(\%)\end{array}$ & $0,33 \pm 4,0 \times 10^{-3 \mathrm{~b}}$ & $0,30 \pm 2,0 \times 10^{-3 \mathrm{a}}$ \\
Kadar & $14,07 \pm 0,11^{\mathrm{a}}$ & $15,55 \pm 0,04^{\mathrm{b}}$ \\
karbohidrat (\%) & & \\
$\begin{array}{l}\text { Aktivitas } \\
\text { antioksidan (ppm }\end{array}$ & $553,40 \pm 0,35^{\mathrm{b}}$ & $507,98 \pm 0,35^{\mathrm{a}}$ \\
AEAC) & & \\
\hline Keterangan: Angka & & \\
\hline
\end{tabular}

Keterangan: Angka yang diikuti huruf yang sama pada parameter yang sama menunjukkan bahwa kedua produk tidak berbeda nyata $(P>0,05)$, sedangkan angka yang diikuti huruf yang berbeda pada parameter yang sama menunjukkan bahwa kedua produk berbeda nyata $(P<0,05)$

Aktivitas antioksidan kuah jahe formula optimal $(551,20 \pm 0,71)$ lebih tinggi dibandingkan kuah jahe tradisional $(507,98 \pm 0,35)$. Hal ini disebabkan oleh adanya subtitusi jahe merah pada pembuatan kuah jahe optimal. Berdasarkan penelitian Herold (2007), jahe merah memiliki aktivitas antioksidan $(849,19$ ppm AEAC) lebih tinggi dibandingkan dengan jahe emprit $(844,50$ ppm AEAC).

\section{Karakteristik sensori kuah jahe optimal dan kuah jahe tradisional}

Tingkat kesukaan panelis terhadap kuah jahe tradisional dan formula optimal dapat dilihat pada Gambar 4. Respon aroma, rasa, warna, dan overall menunjukkan bahwa dua formula kuah jahe tersebut cukup disukai panelis (skala nilai 5). Tingkat kesukaan terhadap aroma kuah jahe formula optimal $(5,60 \pm 0,92)$ lebih tinggi dibandingkan aroma kuah jahe tradisional $(5,47 \pm 1,09)$. Perbedaan tingkat kesukaan dapat disebabkan adanya variasi jenis jahe yang digunakan. Selain itu, aroma kuah jahe juga dipengaruhi oleh kandungan minyak atsiri jahe yang digunakan. 


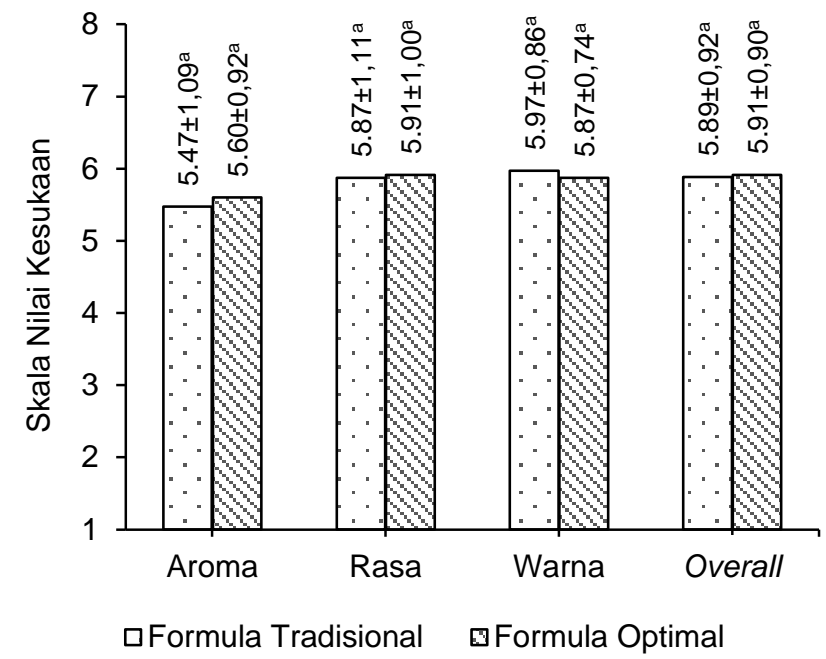

Keterangan: Angka yang diikuti dengan huruf yang berbeda pada parameter yang sama menunjukkan bahwa kedua produk berbeda nyata $(P<0,05)$

Gambar 4. Respon kesukaan kuah jahe formula tradisional dan kuah jahe formula optimal

Aroma kuah jahe formula optimal dengan kombinasi jahe merah dengan jahe emprit lebih disukai panelis dibandingkan formula tradisional yang hanya dengan jahe emprit. Hal ini diduga kandungan senyawa volatil (minyak atsiri) jahe merah lebih tinggi dibandingkan jahe emprit. Semakin tinggi kandungan minyak atsiri akan menghasilkan intensitas aroma yang semakin kuat. Rasa kuah jahe formula optimal $(5,91 \pm 1,00)$. lebih disukai dbandingkan kuah jahe tradisional $(5,87 \pm$ 1,10). Tingkat kesukaan terhadap rasa kuah jahe sangat dipengaruhi oleh konsentrasi jahe emprit yang digunakan. Kuah jahe formula tradisional menggunakan konsentrasi jahe emprit yang lebih tinggi sehingga terasa lebih pedas. Hal ini sejalan dengan yang dikemukakan Yuliani dan Kauliku (2009) bahwa jahe emprit menghasilkan rasa pedas yang lebih tinggi dibandingkan dengan jahe merah. Warna kuah jahe formula optimal $(5,87 \pm 0,74)$ kurang disukai dibandingkan kuah jahe formula tradisional $(5,96 \pm 0,86)$. Perbedaan warna kuah jahe tersebut disebabkan oleh perbedaan konsentrasi gula merah yang ditambahkan. Menurut Ibrahim et al. (2015), panelis cenderung kurang menyukai ekstrak jahe dengan warna gelap. Semakin gelap warna suatu produk ditunjukkan dengan nilai $L$ yang mendekati nol. Secara keseluruhan (overall), kuah jahe formula optimal memiliki tingkat kesukaan $(5,91 \pm 0,90)$ lebih tinggi dibandingkan kuah jahe formula tradisional $(5,89 \pm$ $0,92)$. Namun demikian hasil uji T $(P>0,05)$ menunjukkan bahwa tingkat kesukaan panelis terhadap aroma, rasa, warna dan overall kuah jahe formula optimal tidak berbeda signifikan antara dan kuah jahe tradisional.

\section{Karakteristik sensori wedang tahu formula optimal dan formula tradisional}

Respon kesukaan panelis terhadap wedang tahu formula tradisional dan wedang tahu formula optimal dapat dilihat pada Gambar 5. Rata-rata panelis lebih menyukai wedang tahu formula optimal dibandingkan wedang tahu tradisional, baik dari respon aroma, warna, rasa, tekstur, maupun secara keseluruhan (overall).

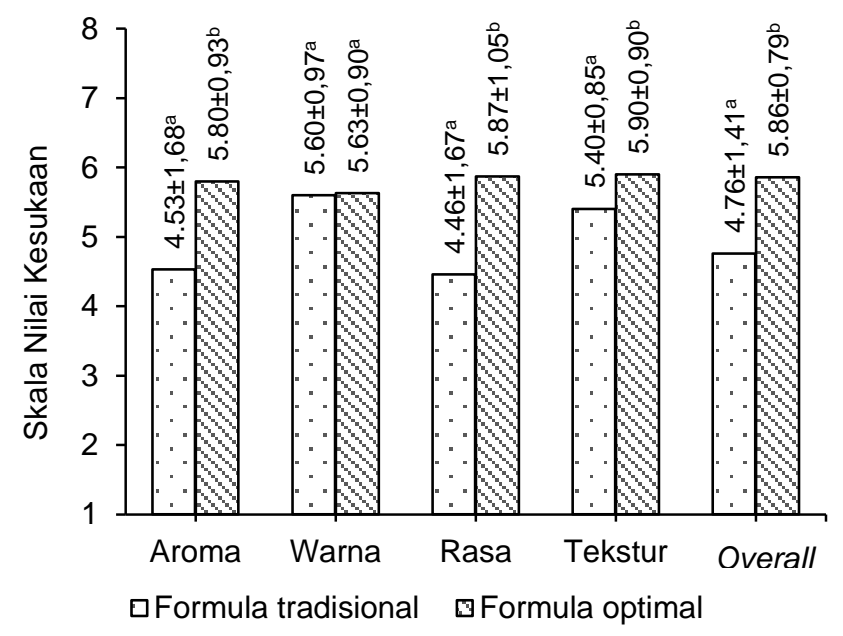

Keterangan: Angka yang diikuti dengan huruf yang berbeda pada parameter yang sama menunjukkan bahwa kedua produk berbeda nyata $(P<0,05)$

Gambar 5. Tingkat kesukaan wedang tahu formula optimal dan tradisional

Tingkat kesukaan panelis terhadap aroma wedang tahu formula optimal $(5,84 \pm 0,88)$ lebih tinggi dibandingkan wedang tahu tradisional $(4,53 \pm$ 1,68). Karakteristik sensori wedang tahu dipengaruhi oleh dua komponen utama penyusunnya, yaitu kuah jahe dan tahu lembutnya. Aroma wedang tahu dapat dipengaruhi oleh adanya kandungan minyak atsiri dari kuah jahe dan bau langu dari tahu lembut yang ditimbulkan. Rata-rata panelis kurang menyukai aroma wedang tahu formula tradisional karena adanya aroma langu yang diduga karena cara pengolahan kedelai yang kurang tepat dalam pembuatan tahu lembut. Menurut Indrastuti (2016), warna, aroma, rasa, dan tekstur tahu lembut yang dibuat dengan formula optimal lebih disukai panelis dibandingkan tahu lembut yang dibuat dengan formula tradisional dari pedagang. Bau langu disebabkan oleh aktifnya enzim lipoksigenasi pada kedelai yang akan bereaksi dengan lemak sewaktu dinding sel pecah oleh penggilingan, terutama jika penggilingan dilakukan secara basah pada suhu 
dingin. Penggunaan air panas $\left(80-100^{\circ} \mathrm{C}\right)$ dapat menginaktivasi enzim lipoksigenase (Maryam, 2007). Tingkat kesukaan yang rata-rata panelis terhadap warna wedang tahu formula optimal $(5,79$ $\pm 1,03$ ) lebih tinggi dibandingkan tingkat kesukaan terhadap warna wedang tahu tradisional (5,60 \pm $0,97)$. Tingkat kesukaan rata-rata panelis terhadap rasa wedang tahu formula optimal adalah 5,79 \pm 0,95 , sedangkan untuk rasa wedang tahu formula tradisional 4,46 $\pm 1,67$. Rata-rata panelis kurang menyukai rasa yang dihasilkan wedang tahu formula tradisional karena terdeteksi rasa pahit dan getir. Rasa pahit pada kuah jahe dapat disebabkan oleh adanya senyawa shogaol pada jahe (Putri, 2011), sedangkan rasa getir disebabkan oleh penggunaan bahan penggumpal yang digunakan pada pembuatan tahu lembut, yaitu kalsium sulfat (Novitasari, 2014). Respon kesukaan terhadap tekstur wedang tahu formula tradisional $(5,43 \pm 1,3)$ lebih kecil dibandingkan terhadap tekstur wedang tahu formula optimal $(5,94 \pm 0,85)$. Tekstur tahu lembut pada wedang tahu formula tradisional lebih lunak dan cenderung mudah hancur sehingga mempengaruhi tingkat kesukaan panelis terhadap tekstur wedang tahu. Berdasarkan hasil uji T (T-test), respon kesukaan terhadap parameter aroma, rasa, tekstur, dan overall dari wedang tahu formula optimal berbeda signifikan dibandingkan wedang tahu formula tradisional $(P<0,05)$. Namun, respon ke-sukaan terhadap warna wedang tahu formula optimal dan tradisional tidak berbeda signifikan $(P>0,05)$.

\section{KESIMPULAN}

Jahe merah memiliki kadar air $84,57 \%$ dengan aktivitas antioksidan 849,19 ppm AEAC, sedangkan jahe emprit memiliki kadar air 80,55\% dengan aktivitas antioksidan 844,05 ppm AEAC. Berdasarkan optimasi yang dilakukan, diperoleh formula kuah jahe optimal dapat diperoleh dengan komposisi bahan baku berupa jahe merah $10,00 \%$, jahe emprit $9,99 \%$, dan gula merah $10,00 \%$. Formula tersebut menghasilkan aktivitas antioksidan sebesar 553,40 ppm AEAC yang lebih tinggi dibanding kuah jahe tradisional, serta nilai kecerahan warna (L) 40,03, serta nilai Hue 74,67 . Nilai respon kesukaan panelis terhadap rasa, aroma, dan overall dari kuah jahe formula optimal lebih tinggi dibandingkan kuah jahe formula tradisional. Demikian juga untuk wedang tahu, warna, aroma, rasa, tekstur, dan overall wedang tahu formula optimal lebih disukai panelis dibandingkan wedang tahu formula tradisional.

\section{DAFTAR PUSTAKA}

Ali BH, Blunden G, Tanira MO, Nemmar A. 2008. Some phythochemical, pharmacological, and toxicological properties of ginger (Zingiber officinale Roscoe): A review of recent research. Food Chem Toxicol 46: 409-420.

[AOAC] Association of Official Analytical Chemist. 2012. Official Methods of Analysis Washington DC (USA). $19^{\text {th }}$ Edition. AOAC International.

Battarai S, Tran VH, Duke CC. 2001. The stability of gingerol and shagaol in aqueous solitions. $J$ Pharm Sci 90: 1658-1664. DOI: 10.1002/ jps.1116.

[BPOM] Badan Pengawasan Obar dan Makanan. 2011. Pereturan Kepala (Perka) Badan Pengawas Obat dan Makanan Republik Indonesia Nomor HK.03.1.23.11.11.09909 tahun 2011 tentang Pengawasan Klaim dalam Label dan Iklan Pangan Olahan. BPOM RI Tahun 2011.

[BSN] Badan Standarisasi Nasional. 1992. SNI 013179-1992: Jahe Segar. Jakarta: BSN.

[BSN] Badan Standarisasi Nasional. 2006. SNI 012346-2006: Petunjuk Pengujian Organoleptik dan atau Sensori. Jakarta: BSN.

[Depkes RI] Departemen Kesehatan Republik Indonesia. 2010. Pedoman Standar Umum Ekstrak Tanaman Obat. Jakarta: Depkes RI.

Fayed FA. 2009. Antioxidant and anticancer activities of citrus reticulate (Petitgrain mandarin) and pelargonium graveolens (geranium) essential oils. Res J Agr Bio Sci 5: 740-747.

Haryanto D. 2009. Studi penentuan nilai resistor menggunakan seleksi warna model HSI pada citra 2D. J Telkomnika 7: 13-22.

Herold. 2007. Formulasi minuman Berbasis Kumis Kucing (Orthosiphon aristatus BI. Miq) yang Didasarkan pada Optimasi Aktivitas Antioksidan, Mutu Cita Rasa, dan Warna. [Skripsi]. Bogor (ID): Fakultas Teknologi Pertanian, Institut Pertanian Bogor.

Hidayati IL. 2007. Formulasi Tablet Effervescent dari Ekstrak Daun Belimbing Wuluh (Averrhoa belimbi L.) sebagai Anti Hipertensi. [Skripsi]. Bogor (ID): Institut Pertanian Bogor.

Ibrahim AM, Yunianta, Sriherfyna FH. 2015. Pengaruh suhu dan lama waktu ekstraksi terhadap sifat kimia dan fisik pada pembuatan minuman sari jahe merah (Zingiber officinale var. Rubrum) dengan kombinasi penambahan madu sebagai pemanis. J Pangan Agr 3: 530541.

[IFT] Institute of Food Technologists. 2011. What are antioxidants and why do you need them? Source Newsroom: Institute of Food Technologists Article ID: 580241 [Internet]. http://www. newswise.com/articles. [20 September 2016]. 
Indrastuti NA. 2015. Optimasi Penggunaan Kalsium Sulfat dan Karaginan pada Pembuatan Tahu Lembut [Skripsi]. Bogor (ID): Fakultas Teknologi Pertanian, Institut Pertanian Bogor.

Huntching JB. 1999. Food Color and Apperance. New York: Springer Publisher. p 610: 544-545.

Julianti E, Ridwansyah, Nurminah M. 2010. Pengeringan kemoreaksi dengan kapur api (CaO) untuk mencegah kehilangan minyak atsiri. J Teknol Industri Pangan 21: 51-58.

Leon K, Leon J, Mery D, Pedreschi F. 2006. Color measurement in $L^{*} a^{*} b$ units for RGB digital images. Food Res Int 36: 1084-1091. DOI: 10.1016/j. foodres.2006.03.006.

[LPI] Linus Pauling Institute. 2016. The new recommendations for dietary antioxidants: A response and position statement by the Linus Pauling Institute. Oregon State University [Internet]. http://lpi.oregonstate.edu/new-recommendations-dietary-antioxidants-response-andpositionstatement-linus-pauling-institute.

[20 September 2016].

Mayani L, Yuwono SS, Ningtyas DW. 2014. Pengaruh pengecilan ukuran jahe dan rasio air terhadap sifat fisik kimia dan organoleptik pada pembuatan sari jahe. J Pangan Agr 2: 148-158.

Marliyana SD, Kusumaningsih $T$, Kristinawati $H$. 2006. Penentuan kadar total fenol dan aktivitas antioksidan ekstrak kulit biji ketapang (Terminalia cattapa L.). J Alchemy 5: 39-44.

Maryam S. 2007. Penentuan suhu optimum air saat menggiling kedelai untuk menghasilkan tahu berkualitas. J Penel Peng Sains Humaniora 1: 156-167.

Meilgaard MC, Carr BT, Civille GV. 2006. Sensory Evaluation Techniques 4th Ed, p 464: 101-124. New York: CRC Press.
Novitasari IA. 2014. Pemanfaatan Biji Munggur sebagai Bahan Dasar Pembuatan Tahu dengan Penambahan Sari Jeruk Nipis (Citrus aurantifolia) dan belimbing wuluh (Averrhoa bilimbi) sebagai Penggumpal. [Skripsi]. Surakarta. Fakultas Keguruan dan IImu Pendidikan-Pendidikan Biologi, Universitas Muhammadiyah Surakarta.

Oktora R, Aylianawati D, Sudaryanto Y. 2007. Ekstraksi oleoresin dari jahe. Widya Teknik 6: 131-141.

Puengphian C, Sirichote A. 2008. [6]-gingerol content and bioactive properties of ginger (Zingiberofficinale roscoe) extracts from supercritical CO2 extraction. As J Food Ag-Ind 1: 2936.

Putri HSI. 2011. Pengaruh Penambahan Ekstrak Jahe (Zingiber officinale Roscoe) terhadap Aktivitas Antioksidan, Total Fenol, dan Karakteristik Sensori pada Telur Asin. [Skripsi]. Surakarta. Fakultas Pertanian, Universitas Sebelas Maret.

Septiana AT, Dwiyanti H. 2009. Aktivitas antioksidan minuman fungsional dari irisan buah kering mahkota dewa. J Agritech 29: 16-21. DOI: 10.22146/agritech.9756.

Sovia E, Sukandar EY, Sasongko LDN, Ligit JI. 2011. Aktivitas inhibisi ekstrak bawang putih dan S-metil sistein terhadap reaksi glikasi albumin secara in vitro. J Kedokteran Maranatha 10: 98-109.

Yuliani S, Kauliku SI. 2009. Pengembangan produk jahe kering dalam berbagai jenis industri. Bul Teknol Pasca Pertanian 5: 61-68. 